Historia Slavorum Occidentis

2018, nr 4 (19)

ISSN 2084-1213

DOI: $10.15804 /$ hso180405

Marián ManÁK (Trnava)

\title{
Insights of the French Military Mission Representatives to Czechoslovakia into the Offensive Plans of the Republic and the Functioning of the Czechoslovak Army in $1919-1925^{1}$
}

Słowa kluczowe: francuska misja wojskowa, armia czechosłowacka 1918-1938, układ monachijski

Keywords: French Military Mission, Czechoslovak Army 1918-1938, Munich agreement

\begin{abstract}
The study focuses on some selected aspects of the activity of the French military mission in Czechoslovakia in the inter-war period, mainly on the analysis of the French military personnel of the mission that acted in the strategic functions, influenced the plans of the country defence in the case of an enemy attack and includes the opinions of the French commanders on the structure and function of the Czechoslovak army.
\end{abstract}

The process of the establishment of a common state of Czechs and Slovaks from the debris of the Austrian-Hungarian Monarchy is characterised by the absence of legally and internationally guaranteed borders, as well as the complicated inner-political conditions of republic coming into existence. Apart from the Czech frontier areas

\footnotetext{
1 The article is based on the study of the grant project of the Ministry of Education, Science, Research and Sports of the Slovak Republic VEGA 1/0438/18 Diplomatic and economic relations between Czechoslovakia and the USA in the first half of the 20th century (Diplomatické a hospodárske vzt'ahy medzi Československom a USA v 1. polovici 20. storočia).
} 
and Těšín region, the most significant problem of the Czech government was the establishment and re-enforcement of a new state power in Sub-Carpathian Ruthenia, prevailingly in Slovakia. The new Hungarian government of count Mihály Károlyi refused to forego these territories as former parts of Hungary. ${ }^{2}$ The Czechoslovak Republic was in a difficult military-political situation, practically without their own army as tens of thousands of the members of the Czechoslovak legions were still located in Russia, France and Italy. In the initial stage of its existence, the new republic had only newly-formed units of a home defence army, organised from volunteers, which were weakly armed irregular troops in small numbers. ${ }^{3}$

In this uneasy and complicated situation, the government of the Czechoslovak Republic tried to achieve any stabilising element that would help usher the state and its defensive power into a democratic and peaceful life. Therefore, the Minister of Foreign Affairs of the Czech Republic, Edvard Beneš, officially addressed the French government to send a military mission to the Czechoslovak Republic, ${ }^{4}$ whose primary role should have been the organisation of the Czechoslovak army and education of the new officer staff. The first part of the French military mission (further on FMM) arrived in Prague on $13^{\text {th }}$ February 1919 headed by the divisional general, Maurice Pellé. ${ }^{5}$ From the beginning he acted as a deputy of general Pierre Thiebaut, Charles Janin, ${ }^{6}$ later as a head of the FMM he was working in this function by $31^{\text {st }}$ December 1920, when he was replaced by general Eugène Mittelhauser. Apart from military duties, Pellé performed the instructions given during his departure to Prague from the French Prime Minister, George Clemenceau, to act in favour of the dominance of French influence and create the best military institutions, focusing on all possible areas of social life - from diplomatic through economic, business, cultural and others. The position of Pellé became significantly stronger in $4^{\text {th }}$ June 1919 ,

2 B. Ferenčuhová, Vznik Československa a začlenenie Slovenska do nového štátu, [in:] Bratislava 2012, pp. 17-38; L. Lipták, Slovensko v 20. Storočí, Bratislava 1968, pp. 79-84.

3 M. Čaplovič, P. Petruf, Francúzska vojenská misia v Československu 1919-1938. (Správa o jej činnosti od februára do októbra 1919), [in:] Vojenská história 5, (2001), No. 4, pp. 85-86.

4 It is necessary to add that in that time another military mission - Italian - was active on the territory of the Czechoslovak Republic. It was headed by the commander of the Czechoslovak legions in Italy, general Luigi Piccione. In detail: M. Hronský, Talianska vojenská misia v začiatkoch ČSR, [in:] História. Revue o dejinách spoločnosti, 2, 2002, No. 3, pp. 19-21.

5 M. Čaplovič, Francúzska vojenská misia v ČSR 1919 - 1938, [in:] Nová História. Revue o dejinách spoločnosti, 2, (2002), č. 3 (máj/jún), supplement: Slovensko do Severoatlantickej aliancie, p. 22.

6 Since 27th February 1918, Janin held the post of the chief commander of the Czechoslovak legions abroad, since October 1918 he was the commander of all armies of the Agreement on Siberia. 
when after the invasion of the army of the Hungarian Republic of Orders into Slovakia he was appointed the main commander of the Czechoslovak army. His nomination was met by a significant displeasure with general Piccione, which resulted in the consequent worsening of relations between the delegates of the Czechoslovak Republic and the representatives of Italy in the peace conference in Paris. Despite this fact, Pellé gradually appointed more than 100 French army officers and generals who led almost all Czechoslovak troops, committed to battles against the Hungarian Red army. The French thus held posts in the Czechoslovak army, approximately two thirds of all posts of higher-rank commanders, ${ }^{7}$ and had command in the central Czechoslovak military organs practically by the beginning of 1926. They occupied the post of the chief of the general staff (general Pellé 1919-1921, general Mittelhauser 1921-1925) and his deputy (general Louis-Eugène Faucher 1919-1926), as well as the post of the chief of the third operational division (general Henri Rozet 1919-1923) and the $5^{\text {th }}$ educational and training division of the headquarters (general Joseph Le Blévec 1920-1926). ${ }^{8}$

The chief of the $3^{\text {rd }}$ operational division, Henri Rozet, held at the same time the function of the head of the operational division of the Headquarters of the Czechoslovak armed forces. Under his guidance, in 1919-1925 the $3^{\text {rd }}$ operational division became a centre, in which the Czechoslovak military doctrine was created, the scenarios of possible conflict (more or less relevant), the ways of using the offensive advantages of the country location were sought and the ways of reducing risks of an isolated defence. The members of the division dealt with the strategic problems of the position of Czechoslovakia in Central Europe: the conception of the national defence, potential participation of the Czechoslovak army in international conflicts and so on.

The activity of the $3^{\text {rd }}$ operational division is recorded in the published collection of the documents, which are stored in the Military Headquarters Archives in Prague and the archives of the Service Historique de la Défense in Vincennes. ${ }^{9}$ Due to the broad extent of the topic dealt by the operational and training division, this article focuses only on selected aspects of its activities, mainly the analysis of the strategic

7 B. Ferenčuhová, Francúzsko a slovenská otázka 1789-1989, Bratislava 2008, pp. 226-228 and 233. 8 M. Čaplovič, P. Petruf M., Francúzska vojenská misia, p. 90.

9 Mission militaire française auprès de la République Tchécoslovaque 1919-1939. Edition documentaire. Serie I: 1919-1925. Volume 4. Réflexions stratégiques, études, plans d'opérations.= Francouzská vojenská mise v Československu 1919-1939. Edice dokumentů.Série I: 1919-1925. Svazek 4. Strategickéúvahy, studie, operačni plány, ed. R. Břach, Praha 2009, p. 385. 
position of the Czechoslovak Republic, the defence plans of the republic in case of being attacked and the opinions of French army officers, concerning the structure and training of the Czechoslovak army.

In the summer of 1921, the $3^{\text {rd }}$ operational division of the FMM elaborated the material on the strategic-political position of the Czechoslovak Republic within Central Europe. ${ }^{10}$ The analysts of the division worked on the assumption that the main condition of ensuring the survival of the newly-developed republic is the establishment of a strong, modern, technically-advanced and morally-developed army, led by competent and prepared military commanders who had cultivated their feeling of responsibility towards their homeland. Two years later, this idea was supported by French marshal Ferdinand Foch in his note from $13^{\text {th }}$ July 1923, addressed to Minister of Foreign Affairs Edvard Beneš. He emphasised that pacifistic ideas and institutions do not suffice to ensure the free existence of Czechoslovakia, nor do they ensure the respect of its neighbours. To be respected by its neighbours, Czechoslovakia had to have the army able to mobilise all the sources of the country, i.e. the army in the purely Czechoslovakian spirit. ${ }^{11}$ This premise is based on the geo-political conditions because the then-current Czechoslovakia was surrounded by countries that were in more or less a hostile mood. The vitally important parts of the country (the Czech Republic and Moravia) were surrounded by Germany, or more precisely, by Austria. Nature barriers that could create natural obstacles formed only a small part of frontiers. What is more, the territory of Czechoslovakia had an elongated and narrow shape which in the case of being attacked could complicate defence and military logistics. The only, relatively safe line of the Czechoslovak borders was the one that separated Czechoslovakia from Rumania and Ukraine. The defence of the republic was not therefore established for the case when Czechoslovakia would stay politically isolated and left at the mercy of the aggressor (which appeared as a false assumption in 1938), but army planners assumed that from the fact that Czechoslovakia made bilateral contracts with Yugoslavia in $14^{\text {th }}$ August 1920 and Rumania on $23^{\text {rd }}$ April 1921 within the Small Agreement. Supported by the allied powers, a structured system of offensive and defensive alliances was required in the future. ${ }^{12}$ Parallel mobilisation and the concentration of the armies of these allies

\footnotetext{
10 Mission militaire française, dok. No. 25, pp. 286-294.

11 Ibidem, dok. No. 35, pp. 335-336.

12 B. Ferenčuhová, Československo v medzinárodnej politike 20. rokov, [in:] Slovensko v 20. storočí. Zv. 3. V medzivojnovom Československu 1918-1939, Bratislava 2012, pp. 59-84.
} 
would harden times for an aggressor (those times Germany, Hungary, as the case may be, Austria) as they would be exposed to the potential threat of being attacked in various places at the same time. This resulted in efforts to enter into military partnership with Yugoslavia and Rumania. With regards to Poland, the Czechoslovak Republic was in a territorial conflict in the Těšín area, northern Slovakia and Spiš. ${ }^{13}$

According to the commander of the FMM, Mittelhausser, if the League of Nations planned to organise allied police forces (this idea never came true practically), these were expected to have their bases in the Czech Republic and Moravia to be able to make effective pressure on the neighbouring countries of Central Europe. In his opinion, if necessary, the territory of the Czech Republic could become a base for an offensive led directly towards Berlin, i.e. along the right bank of the River Labe, where the operations would not be affected by bigger nature obstacles. Large-scale combat aviation, organised by the League of Nations on the territory of Czechoslovakia, would be a threat to Vienna and Budapest for short distances (as well as other strategic cities such as Wroctaw or Dresden), which could significantly eliminate the aggressive efforts of Austria and Hungary and make them maintain neutrality. General Mittelhausser considered the operation based in Higher Silesia (Ratiboř - Nisa - Frenštát pod Radhoštěm) towards Vienna, crossing the territory or the republic, which would completely surround the Czech part of the country and Moravia and separate them from the territory of Slovakia, the most dangerous direction of the attack against the Czechoslovak Republic. The General rightly assumed that the establishment of military-strong Czechoslovakia would become an unbearable threat for Hungary and Germany and he was convinced that the first target of any military effort would be demolishing the Czechoslovak Republic. ${ }^{14}$

In the case of a sudden attack against the republic, led by allied forces of enemy armies, the overall system of the country defence should lie on the combination of a voluntary withdrawal from the front at the most threatened places and tactical manoeuvring against the counter-attack. The military planners of the FMM took into account that some of the less protectable parts of the country would be left temporarily under occupation. At the same time the top army leadership was expected to elaborate an up-dated plan of retaliation with the aim to move the target of the war to the territory of an enemy. In the case of conflicts with Germany, Austria and Hungary, this plan on the territory of the Czech Republic was initially defensive, 
but at the same time offensive (from the territory of Slovakia) towards Austria and Hungary the capital cities of which (Vienna and Budapest) were easily endangered. The reason was the fact that offensive operations against Germany originating from the Czech part of the country were due to the shape of the borders and their mountainous character possible only in a limited extent. ${ }^{15}$

In their plans, the analysts of the 3rd operational division of the FMM took into account various eventualities of possible threat for the Czechoslovak Republic. For these reasons, they elaborated and continuously updated a variety of the advances of the Czechoslovak army in the case of a military conflict. The plan concerning the invasion from Hungary was named Plan $\mathrm{H}$ (Hongrie), ${ }^{16}$ that from Hungary and Poland was called Plan PH, the attack from Germany Plan N (the Slavonic name for Germany is Nemecko) or Plan A (Allemagne) ${ }^{17}$ and due to a possible eruption of riots in Silesia, a series of measures were worked out, called Plan S. ${ }^{18}$ The instructions for the Czechoslovak army had been elaborated for eventualities if the Soviet troops attacked the Polish army in Halic and the Rumanian army in Bukovina in the spring 1921 - Plan B (Bolsheviks). ${ }^{19}$ Apart from a direct military threat to the Republic, the planners took into account a possibility of the renewal of the Monarchy in Bavaria, Austria and Hungary, which was elaborated in detail in the Plan Ludendorff. ${ }^{20}$

\footnotetext{
15 Mission militaire française, doc. No. 25, pp. 286-287.

16 Ibidem, doc. No. 2-5, p. 9 and 28.

17 The preliminary ideas of commander Rozet about basic outlines of the defensive plan from May 1920. Mission militaire française, doc. No. 11.
}

18 After World War I, both Germany and Poland laid claims to the disputed territory of Upper Silesia. According to the conclusions of the Versailles peace treaty this territory was administered by the allied commission that was to prepare a plebiscite about its definite affiliation. The commission determined the date of the plebiscite $-20^{\text {th }}$ March 1921. Plan S included the preliminary regulations for the case of serious riots between Poles and Germans with the aim of preventing them to be transferred to the Czechoslovak border area. Mission militaire française, doc. No. 19 and 20.

$1919^{\text {th }}$ October 1920 the truce under the conditions favourable for Poland was agreed upon in the conflict between the Polish troops and the Red Army. In general, it was expected that after the consolidation of their forces, the Soviets would renew animosity in spring 1921. This eventuality was taken into account in Plan B from January 1921. Mission militaire française, doc. No. 21 and 22. 20 In spring 1921, the former emperor of Austria-Hungary, Charles I of Austria, left his exile in Switzerland and arrived in Hungary, where he tried to take power from admiral Horthy, with whom he did not reach an agreement. Charles I did not take into account serious objections concerning internal political problems, mainly potential intervention of the former allied powers, or declaration of war from some successor states of the monarchy (Czechoslovakia, Rumania and Yugoslavia). Under the pressure of the allies, the former emperor had to withdraw. This incident was a stimulus 
As far as the territory of Slovakia is concerned, plans $\mathrm{H}$ and $\mathrm{PH}$, which means the attack of Hungarian, as the cause may be Polish armies. Despite the fact that a military conflict between Hungary and Czechoslovakia ended by truce on $23^{\text {rd }}$ June 1919, agreed by the commander-in-chief of the Czechoslovak army, Maurice Pellé and the commander-in-chief of the Hungarian army, Vilmos Böhm, the situation in Slovakia remained uncertain. The Hungarian army withdrew from the territory of the western part of Slovakia under pressure of the allied powers on $3^{\text {rd }} \mathrm{July}$, from the eastern part of Slovakia two days later, however it continued to remain concentrated near the Slovak borders. The situation was complicated by the commencement of a new regime of admiral Miklós Horthy in Budapest, who substituted the government of the Republic of Orders. From the truce to signing a peace treaty in Trianon on $5^{\text {th }}$ June 1920, a serious tension lasted between Czechoslovakia and Hungary, which was reflected in the defensive plans of the FMM in the case of a new attack.

According to the experts of the 3rd operational division of the FMM, the Danube River formed a natural border in the south of Slovakia, which was so big that an enemy could not get over it by a direct attack. The two places of probable crossing the borders were Bratislava (even though hidden by a Petržalka bridgehead) and Komárno which might be protected from the left bank of the river. The Danube front was protected by the left-bank estuaries (the Hron, the Nitra, the Váh) creating a north-southern line of defence protecting Bratislava against attack from the eastern side. The Hungarian army target related to the east of the Danube was probably based on reaching Žilina (across Turiec), which might result in the seizure of an important crossroad, which was the only railway connection with eastern Slovakia. To the East, the valley of the Hornád, which opened the shortest way towards the north, might have attracted the Hungarians to invite the Poles into a military expedition. Two cities - Košice and Prešov - were threatened to be occupied, which might have resulted in the severance of the relations Czechoslovakia and Sub-Carpathian Russia. ${ }^{21}$ It is interesting that all the plans concerning conflict with Hungary took into account the counter-attack of the Czechoslovak army and the occupation of Budapest.

Lines of communication played an important role in the defence of the country. In this perspective, the position of the Czechoslovak Republic was complicated as

to elaborate the operational study, the name of which is derived from the name of the German general, who was actively engaged in the anti-democratic movement in Bavaria. Mission militaire française, doc. No. 24.

21 Mission militaire française, doc. No. 27, p. 304. 
the countries the republic consisted of had an inferior status to different political and economic orientations - while the Czech and Moravian parts inclined to Austria, Slovakia as a part of Hungary was communicatively connected to Budapest. ${ }^{22}$ The railway lines star-shaped heading from Prague to all sides enabled the Czech part to have a complete connection and were linked to the networks of neighbouring countries (Bavaria, Alsace, Silesia, Austria) without problems. The railway network was mutually connected as there did not exist any natural barriers between an imaginary border between the Czech part and Moravia. Apart from this, Moravia was traditionally a territory that connected Lower Austria with German lowland on the north, and therefore important communications crossed the country from the southwest to the northeast (the railway track from Vienna to Bohumín).

Another situation was seen between Moravia and Slovakia. The highland country of Slovakia, lying from the Carpathian ranges to the Hungarian lowland, had tips heading from north to south. Practically, all the most important rivers ran to Hungary. It was comprehensible that the roads and railways naturally copied these natural tracks, but a new Slovak-Hungarian border expectedly intersected these paths. The railway connection between the Czech countries and Slovakia was insufficient in the first years of the existence of the Czechoslovak Republic and was possible only by means of three tracks: $1^{\text {st }}$ track: Přerov-Bohumín-Těšín, leading across the Jablunkov pass to Žilina, was the only fast and gross-capacity two-tracked connection with the eastern part of Slovakia; $2^{\text {nd }}$ track Brno-Trenčianska Teplá, surmounting the Small Carpathians across the Vlár pass, was only one-track railway with high mounting and a number of curves. With its capacity of 15 wagons, the track was insufficient for an intensive military performance, what is more, during spring floods, problems with its passability occurred; $3^{\text {rd }}$ track Brno-Břeclav-Bratislava was originally one-track, although the first construction changes started to be carried out the tract between Břeclav a Bratislava was changed into a two-trackrailway. From the perspective of better communication transportation accessibility and defensive assurance of the country, the FMM suggested that in the nearest period the central track (Trenčianska Teplá - Košice) should be established far from the endangered southern borders, the capacity passability of the track across the Vlár pass could be improved by digging the tunnel, the missing railway tracts should be built and mutu-

22 L. Hallon, Hospodársky vývin po vzniku ČSR a v 20. rokoch, [in:] Slovensko v 20. storočí. Zv. 3. V medzivojnovom Československu 1918-1939, p. 216. 
ally connected and the total orientation of the railways should be changed towards the eastern-west direction. ${ }^{23}$

Another report, elaborated by the $2^{\text {nd }}$ general division of the military headquarters, by the section of the foreign army, provided detailed data about the state of the newly-established Czechoslovak army. The number of the army by September the $24^{\text {th }} 1921$ (when the internal administration came into existence) accounted for 125,000 men (two years of recruits born in 1899 and 1900), out of which 115,000 accounted for the men and officers and 10,000 officers of command, who were distributed into 12 infantry divisions, 2 mountain brigades and 10 border battalions. Disregarding detailed military information, the views of the French corps of generals on the characteristics of the representatives of single nationalities in the Czechoslovak army seem to be interesting. According to the high command of the FMM, from the physical perspective, the Czechs were considered patient, sober and heavy-duty. At the same time, they were patriots, but not militarists, who considered evasion of military duties as patriotic acts in Austria-Hungary, which they were not able to get rid of after the establishment of the republic. In the French officers' opinion, the Slovaks were a nation of tough ancient villagers, who had predispositions to become good soldiers. The difference between the two nations was mainly recognisable in religion affairs. While a Czech was indifferent, a Slovak was a confirmed Catholic, complying with religious duties and very attached to clergy, which led to many misunderstandings and conflicts (mainly from the first post-war years). They were caused mainly by the ineptitude of the Czech administration and religious insensitivity, which, on the other hand, resulted from the situation that the priests in Slovakia (whose opinions were given significance) were mostly Hungarophiles and their functioning and activities did not contribute to bring close the attitudes of Czechs and Slovaks to each other. On the contrary, the Czechs admitted faults they had committed and therefore it was possible - according to the reports of the French officers - to take into consideration the full loyalty of the Slovaks.

The evaluation of the French mission included briefly the notion of the Ruthenians, considered strongly underdeveloped villagers, living in the multinational territory of the Sub-Carpathian Ruthenia. The FMM considered the Hungarians as a weakness of the Czechoslovak army due to their irredentism and animosity towards the Czechs. They themselves did not mean a great danger. However, it could be multiplied by the presence of Czechoslovak Germans in the army, who had not 
been represented there by October 1920. The German element was the most unlikely for the French generals from all those the Czechoslovak army comprised of. In this context, another statement of the report that German conscripts were known for their good behaviour, obedience and discipline seems to be interesting. They showed a similar mentality of subordination and obedience that is typical for the German race, related either to Germans from the Czech part of the country or the Reich.

In total, the Czechoslovak army missed a necessary homogeneity. It was caused not only by the representation of various nations, but also due to the fact that part of the officers came from old imperial or royal armies, others from the legions that were formed in a totally different environment and under different conditions. It cannot be disregarded that the officers of the Czechoslovak army (similarly as other state officials) were then poorly paid. The recruitment of new officers was very challenging, mainly it was not possible to attract the representatives of the national elite or wealthy classes to start their military career. ${ }^{24}$

The role of the FMM in the improvement of the Czechoslovak army gradually started to bring the first effects, which is supported by a report of the dispatched officer of the general staff lieutenant Dosse ${ }^{25}$ about the manoeuvres of the Czechoslovak army, which were held two years later, on $5^{\text {th }}-7^{\text {th }}$ September 1923. According to his report, the view on the course of the military exercise was very similar to that visible in France. He stated that the Czechoslovak army was well trained, reflecting the military exercise of the French army - according to their regulations and methods. He noticed certain drawbacks/deficiencies - a Czechoslovak soldier was thin as he maintained an unhealthy diet due to the prices; although the soldiers always looked clean, were very disciplined, greeted their higher-ranking officers with due respect

24 Ibidem, dok. No. 29, pp. 306-309.

25 Apart from his participation in the manoeuvres, lieutenant Dosse observed negotiations of general staffs about an agreement on alliance of military convention. One of the later achievements of the negotiations was the signing of the Treaty of Alliance and Friendship between France and Czechoslovakia on $25^{\text {th }}$ January 1924 (in mid-October 1925, it was extended by an agreement on mutual guarantees, elaborated also by the representatives of the FMM. B. Ferenčuhová, Rokovanie o francúzsko-československú zmluvu o spojenectve a priatel'stve (máj 1923 - január 1924), [in:] Slovanské historické štúdie, Vol. 23, (1997), pp. 79-89; P. Petruf, Zmluva o priatel'stve a spojenectve medzi Československom a Francúzskom z roku 1924 a jej odraz v slovenskej tlači, [in:] Historický zbornik, 10, No. 2, (2000), pp. 46-57; idem, Expozé československého vyslanca vo Francúzsku Štefana Osuského o československo-francúzskej spojeneckej zmluve z januára 1924, [in:] Slovensko a Československo v XX. storočí, Bratislava 2010, pp. 51-80. 
and standing at attention. From the military-tactic viewpoint, according to lieutenant Dosse, another weakness of the Czechoslovak soldier was more significant - he was a little slow, and 'Slavic'. Although familiar with the terrain, he does not move faster to overcome the zone of crossfire or to deliver a command. He does not possess agility and freshness of their French comrade; he seems not to have a drive or initiative. Unlike other French commanders that had direct experience with battle on the territory of Slovakia, commander Dosse had information that a Czechoslovak soldier is brave. ${ }^{26}$

As he stated further in his report, several years after the war the conflicts between legionary and former officers of the Austria-Hungarian army continued. The French officers considered the graduates of the military schools of the former Habsburg monarchy as incorrigible deformed by Austrian drill with faulty and bureaucratic opinions, totally divorced from practice, with heavily re-trained mentality stuck to old traditions, sulky and suspicious. As these officers were convinced about the superiority of German methods, in which they had been trained while being contemptuous of French methods, the only possibility of eliminating their influence was based on the gradual decrease of their number in the Czechoslovak army. ${ }^{27}$

The critical view of French observers did not miss the officers from legionaries, who were promoted very quickly in their rankings during the war. Some of them were only about 30 years old. Therefore they had not acquired and received military culture, tactical thinking and they were not able to sufficiently perceive technical development, which occurred during the last years. According to lieutenant Dosse, they believed that during the war only geniality à la Napoleon was enough to achieve results. What is more, some legionaries were considered ambitious, delighted in intrigues/conspiracies and caring for getting a post rather than working on themselves and improving. ${ }^{28}$

In the final evaluation of the military manoeuvres, lieutenant Dosse admitted that the Czechoslovak army represented a serious strength/power and emphasised that the existence of the FMM in Czechoslovakia was long necessary as the commander staff and military headquarters needed to develop solidarity. In the final part of the report, he warned against thinking about an early departure of the FMM, asking questions about what might happen in such a case with this immature body

\footnotetext{
26 Mission militaire française, doc. No. 36, pp. 339-340.

27 M. Čaplovič, P. Petruf, Francúzska vojenská misia, p. 95.

28 Mission militaire française, doc. No. 29, pp. 308-309 and doc. No. 36, pp. 340-341.
} 
whose head and nervous system has been controlled by a French mission. It might be predicted that motionless/immobile arms will fall off and that a completed work - however perfect - will not be permanent. ${ }^{29}$

After all, the FMM remained in Czechoslovakia for the next 15 years, although its function and influence was gradually decreasing. On $1^{\text {st }}$ January 1926 the decree of the president of the republic, Tomáš G. Masaryk, by which he had changed the operation of the FMM as an advisory body came into existence. The chief of staff of the FMM became an advisor to the minister of national defence. His main mission was to provide the minister, as the case may be the chief of the headquarters of the Czechoslovak army with an expert opinion about fundamental issues referring to training and the organisation of the army and follow the form of the teaching process at military schools. During 1938, the relations between Czechoslovakia and France started to be significantly colder, which was caused mainly by politics of the then-prime minister of the French government, Édouard Daladier. The position of Czechoslovakia on the international scene decreased significantly after accepting the Munich agreement by Czech President Edvard Beneš and the Prague government, which meant the beginning of the end of between-war Czechoslovakia. The Munich agreement, signed by France, totally nulled the then-current diplomatic and military efforts of Czechoslovak and French representatives and the activity of the FMM lost its further justification. The FMM definitely ended its activity in the Czechoslovak republic by 31st January 1939. ${ }^{30}$

\author{
Nadesłany: 21 V 2018 \\ Nadesłany po poprawkach recenzyjnych: 21 XI 2018 \\ Zaakceptowany: 22 XI 2018 \\ PhDr. Marián Manák, PhD. \\ Ústav dejín Trnavskej Univerzity \\ Trnavská Univerzita v Trnave \\ Hornopotočná 23 \\ 91843 Trnava \\ marosmanak@gmail.com
}

29 Ibidem, doc. No. 36, p. 345.

30 M. Čaplovič, P. Petruf, Francúzska vojenská misia, p. 24. 


\section{Insights of the French Military Mission Representatives to Czechoslo- vakia into the Offensive Plans of the Republic and the Functioning of the Czechoslovak Army in 1919-1925}

After the establishment of the Czechoslovak Republic in 1918, its government tried to gain some stabilisation elements, which could contribute to the consolidation of the state establishment and its military strength. One was the activity of the French military mission whose primary role was to organise the Czechoslovak army and train new commander staff. The study focuses on some selected aspects of the activity of the French military mission in Czechoslovakia, mainly on the analysis of the French military personnel of the mission that acted in the strategic functions, influenced the plans of the country defence in the case of an enemy attack and includes the opinions of the French commanders on the structure and function of the Czechoslovak army. In the end the Munich agreement, signed in 1938 by French Prime Minister Édouard Daladier totally nulled the then-current diplomatic and military efforts of the Czechoslovak and French representatives. The activity of the French military mission in Czechoslovakia lost its further justification and the mission definitely ended its activity by $31^{\text {st }}$ January 1939. 